\title{
Design and Development of Pin Mill for Size Reduction of Turmeric (Curcuma longa) Rhizome
}

\author{
P.S. Shelake ${ }^{1 *}$, M.N. Dabhi ${ }^{2}$, R.D. Nalawade ${ }^{3}$ and M.L. Jadhav ${ }^{1}$ \\ ${ }^{1}$ Central Institute of Agricultural Engineering, Nabibhag, Bhopal, India \\ ${ }^{2}$ AICRP on PHET, Junagadh Agricultural University, Junagadh, India \\ ${ }^{3}$ Maharana Pratap University of Agriculture and Technology, Udaipur, India \\ *Corresponding author
}

\section{A B S T R A C T}

\begin{tabular}{|l|}
\hline Ke y w o r d s \\
Pin mill, Turmeric \\
rhizomes, \\
Size reduction, Cost \\
economics.
\end{tabular}

\section{Keywords}

Pin mill, Turmeric rhizomes,

Size reduction, Cost

Article Info

Accepted:

Available Online:
In post-harvest operation of spices, grinding is important step. Turmeric rhizomes are generally long size and very hard to grind. In a small grinder, it is not possible to ground whole turmeric rhizome into powder. Cutting of turmeric then generally done manually. In some of the large grinder, the whole turmeric rhizomes fed into the grinder causes heat generation during grinding. The increased temperature during grinding results in loss of flavour and aroma. Cutting of turmeric was the pre-treatment given to the turmeric rhizome before grinding. Design of cylindrical drum, casing, hopper, screen, motor, pulley and supporting frame was done by considering different design consideration. The developed pin mill was having a capacity of $25-27 \mathrm{~kg} / \mathrm{hr}$. Pin mill cut whole turmeric rhizome into small pieces which had the average length, width and thickness of $9.10 \pm 0.51,6.37 \pm 0.29$ and $4.72 \pm 0.32 \mathrm{~mm}$, respectively.

\section{Introduction}

Spices are important agricultural commodities throughout the world due to their high unit price. Spices and condiments are vegetable products or mixtures thereof free from extraneous matter, used for flavouring, seasoning and imparting aroma in foods. The term applies equally to the product in the whole form or in the ground form. It is, therefore, necessary to give attention to this commodity with particular reference to quality and value addition (Purthi, 1998).

Turmeric is one of the most important and ancient spices of India and traditional item of export. Total production of turmeric is 10.93 Lakh tonnes under the area of cultivation of 2.08 Lakh ha (Anon., 2015). Turmeric is mostly produced in Tamilnadu, Telangana, Gujarat, Karnataka and Andhra Pradesh. Highest production of turmeric is found in Tamilnadu state producing nearly 4.62 Lakh tonnes from the area $0.77 \mathrm{Lakh}$ ha (Anon., 2015). It contains 8.5 per cent of protein, 69.9 per cent of carbohydrate and 8.9 per cent of the fat. Turmeric is a rich source of dietary fibre, minerals and vitamins. A $100 \mathrm{~g}$ of turmeric provides around $390 \mathrm{Kcal}$ of energy (Lal, 2012). Volatile oil content in dried 
turmeric is nearly 4-6 per cent and fresh one gives 0.24 per cent essential oil (Pruthi, 1998). Turmeric is extensively used as a spice, food preservative and colouring material. Research studies have suggested that turmeric is also used for medicinal purposes.

Grinding is a very important step in the postharvest processing of spices requiring special attention in order not to lose the aroma and flavour compounds present in them (Gopalkrishnan et al., 1991). During grinding, the temperature of the product rises to a level in the range of $42-95^{\circ} \mathrm{C}$ (Pruthi et al., 1963), which varies with the oil and moisture content of the spices, but spices lose a significant fraction of their volatile oil or flavouring components due to this temperature rise.

Turmeric rhizomes are generally having size near to $54.46 \mathrm{~mm}$ length, $12.48 \mathrm{~mm}$ breadth and $11.32 \mathrm{~mm}$ thickness. Turmeric is very hard to grind i.e. rupture force of turmeric is greater. In a small grinder, it is not possible to ground whole turmeric rhizome into powder. Most of the small spice processors face troubles during grinding of turmeric and also for other hard spices. Cutting of turmeric then generally done manually, it is time and labour consuming operation also does not result in uniform cutting size. In some of the large grinder, the whole turmeric rhizomes fed into the grinder causes heat generation during grinding. The increased temperature during grinding results in loss of flavour and aroma. So, it is necessary to cut whole turmeric rhizome in small pieces. Cutting of turmeric was pre-treatment given to the turmeric rhizome before grinding. Turmeric pieces were then fed into the grinder for grinding.

\section{Materials and Methods}

Physical properties of turmeric were measured. The design of pin mill was done by considering physical properties of turmeric. The study was conducted in Department of Processing \& Food Engineering, College of Agricultural Engineering and Technology, Junagadh Agricultural University, Junagadh. Experiments were conducted during the year 2016-2017.

The designed machine was having following components

\section{Cylindrical drum}

The cylindrical drum made up of MS sheet having a diameter of $65 \mathrm{~mm}$ and length of 80 $\mathrm{mm}$. Pins of MS were cut into the length of 15 $\mathrm{mm}$ and welded on the cylindrical drum up to $5 \mathrm{~mm}$ depth, by drilling hole up to $5 \mathrm{~mm}$ to cut the turmeric rhizome.

This cylinder was fastened to the shaft to connect with an electric motor through $\mathrm{V}$ belt. The shaft was having a diameter of $25 \mathrm{~mm}$. This shaft in casing was fixed by using a bearing.

\section{Casing/Housing}

The casing has a rectangular shape made up with MS sheet of a thickness $5 \mathrm{~mm}$. The rectangular casing was having overall dimensions of $120 \times 120 \times 150 \mathrm{~mm}$.

\section{Hopper}

Thin MS Sheet was used to fabricate feed hopper. An inclination of $65^{\circ}$ with vertical was given to the hopper to avoid backlogging and to have an easy flow of rhizomes. Figure 1 is showing the side and front view of the hopper with respective dimensions.

Separately fabricated hopper was then bolted over the top opening of the casing. To have a control over the feed rate the sliding gate was incorporated in between hopper and casing. 


\section{Screen}

Expected dimension of cut rhizome should have length below $9 \mathrm{~mm}$. Based on this consideration screen was designed. In order to fabricate screen, circular holes of diameter 10 $\mathrm{mm}$ with a pitch of $10 \mathrm{~mm}$ were drilled in MS plate. The screen was then partially bent into curved shape and welded to the bottom opening of the casing. The screen was having overall dimensions of $120 \times 110 \mathrm{~mm}$.

\section{Collector}

The collector having a rectangular shape made up with thin MS sheet. Collector serves the purpose of discharge channel and used to let out size reduced turmeric rhizomes which were dropped through the screen. Collector had a partially curved shape at both ends. Collector is welded to the bottom opening of casing at an angle of $25^{\circ}$. The Collector was having overall dimensions of $103 \times 95 \times 270$ mm.

\section{Electric motor}

The electric motor serves the purpose of prime mover. The electric motor was firmly supported by frame. The motor is having capacity of $1 \mathrm{HP}$ with rated rpm of $1440 \mathrm{rpm}$.

\section{Pulley and belt}

Pulley and belt were used to connect electric motor with the drum. The diameter of pulley has been decided by considering the operating speed of pin mill is $600 \mathrm{rpm}$.

Design of pulley

Motor speed, $\mathrm{R}_{1}=1440 \mathrm{rpm}$

Required speed of pin mill, $\mathrm{R}_{2}=600 \mathrm{rpm}$

Diameter of motor pulley, $\mathrm{D}_{1}=10 \mathrm{~mm}$
So we know that,

$\frac{\mathrm{R}_{1}}{\mathrm{R}_{2}}=\frac{\mathrm{D}_{2}}{\mathrm{D}_{1}} \quad \ldots 1$

$\frac{1440}{600}=\frac{\mathrm{D}_{2}}{10}$

$\mathrm{D}_{2}=24 \mathrm{~mm}$

The diameter of the pulley which mounted on connecting rod $=24 \mathrm{~mm}$.

\section{Supporting frame}

Supporting frame for casing and electric motor is made up of MS angles of size $25 \mathrm{~mm} \times 25 \mathrm{~mm} \times 5 \mathrm{~mm}$ on which the whole assembly with the motor is firmly fixed. Casing with hopper, screen and collector were fixed at height of $610 \mathrm{~mm}$.

\section{Working of pin mill}

Developed pin mill is used for cutting of turmeric rhizome into small pieces. Whole turmeric rhizome sample is fed into the hopper; pin mill is operated by an electric motor trough a $\mathrm{v}$ belt at speed of $600 \mathrm{rpm}$. The feed rate can be controlled by using sliding gate. Cutting of turmeric rhizome was done inside pin mill due to rotating action of the drum on which pins are fitted.

\section{Results and Discussion}

\section{Capacity of pin mill}

The capacity of pin has been calculated in terms of output per unit time. In order to determine capacity of pin mill cutting of 500 gm of turmeric rhizome was done. It was observed that time required for cutting was $1.10-1.20 \mathrm{~min}$ i.e. capacity of $25-27 \mathrm{~kg} / \mathrm{hr}$. Pin mill cut turmeric rhizome into small pieces. 


\section{Properties of cut turmeric pieces}

Whole turmeric rhizome was cut into small pieces which had the average length, breadth and thickness of $9.10 \pm 0.51,6.37 \pm 0.29$ and $4.72 \pm 0.32 \mathrm{~mm}$, respectively. It was also observed that bulk density of cut rhizome pieces was $725.1 \pm 0.00 \mathrm{~kg} / \mathrm{m}^{3}$.

Plate.1 Pin Mill

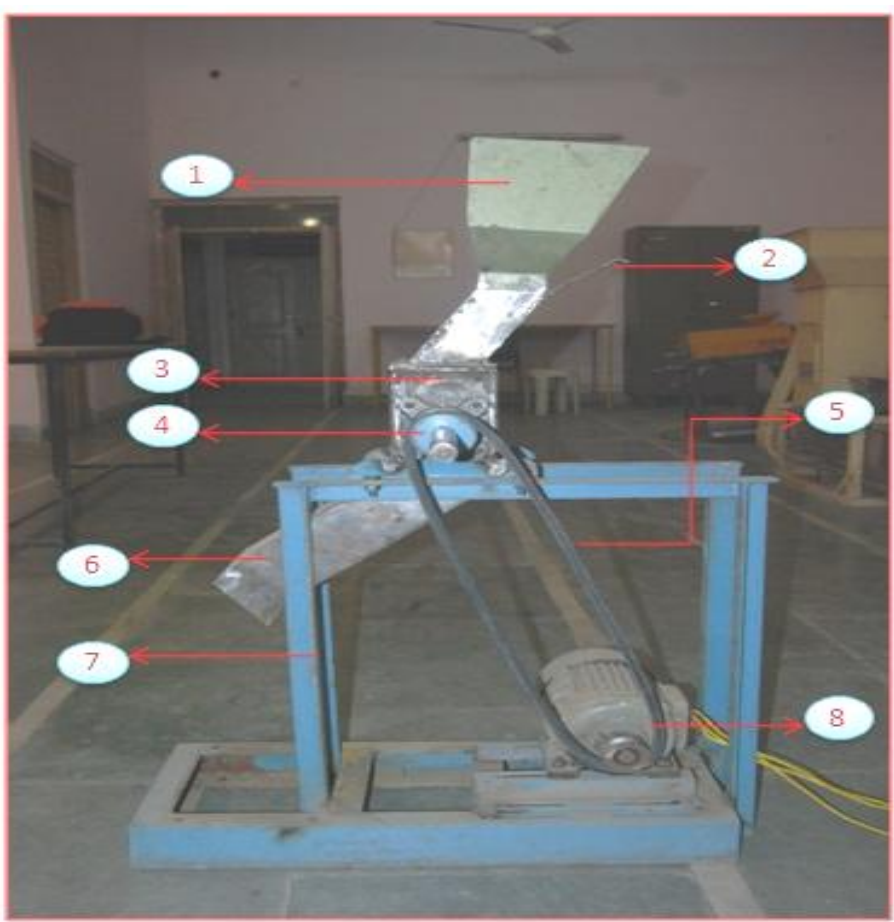

1- Hopper

2- Sliding gate

3- Casing /Housing

4- Pulley

5- Belt

6- Collector

7- Supporting frame

8- Motor

9- Bearing

10- Screen

11- Drum with pin

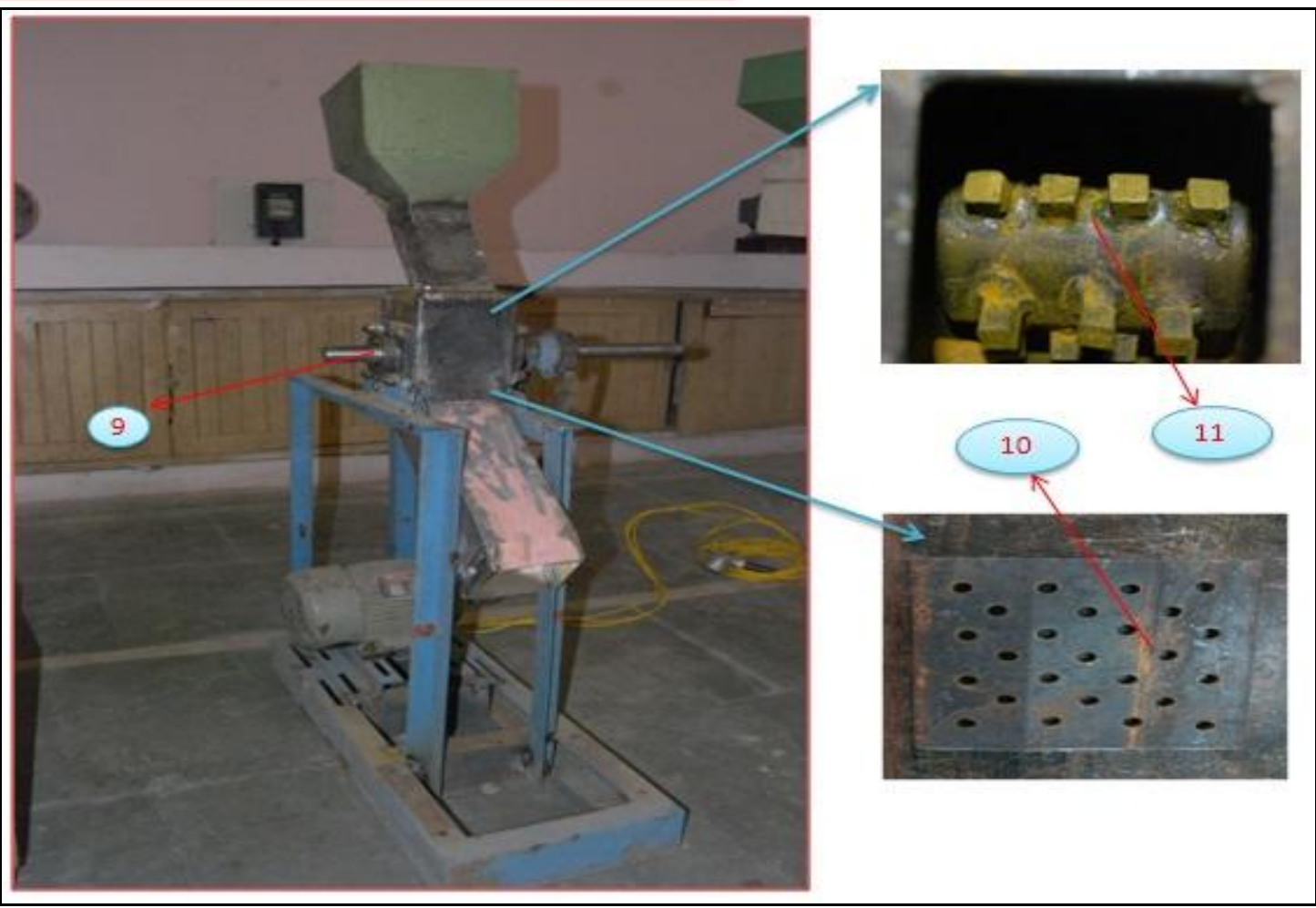


Fig.1 Design of hopper

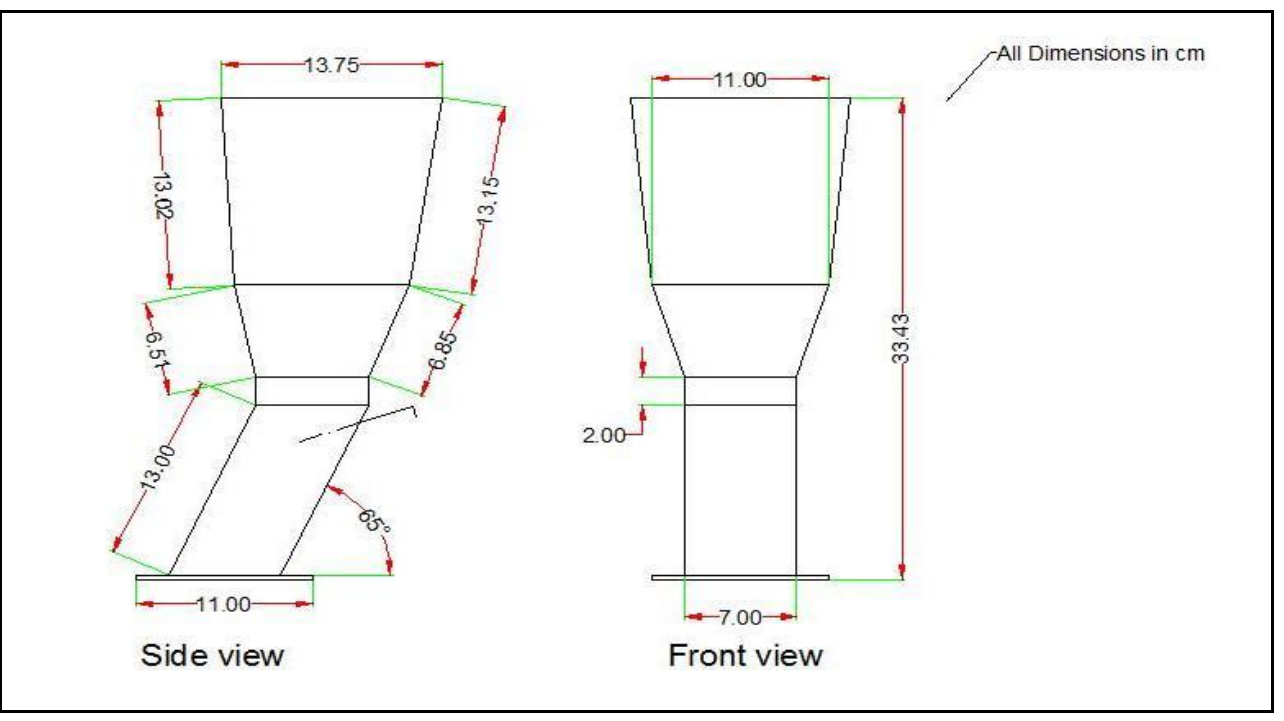

Plate.1 Whole turmeric rhizomes

Plate.2 Cut turmeric pieces
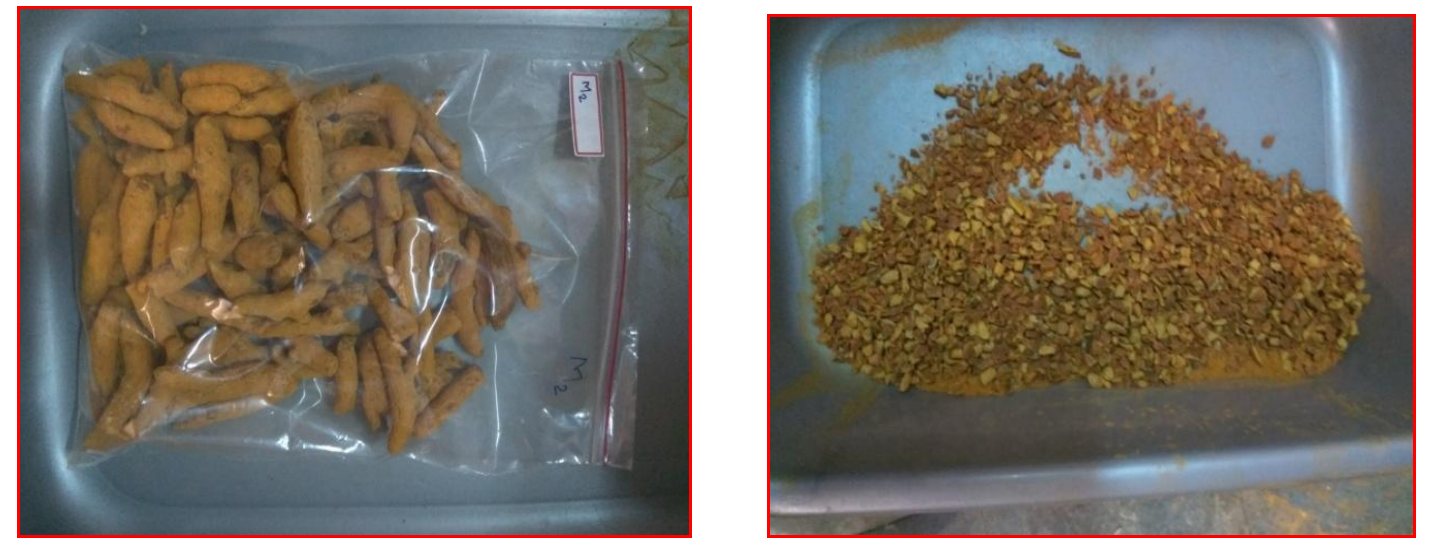

Table.1 Comparison of properties of whole and cut turmeric rhizome pieces

\begin{tabular}{clcc}
\hline Sr. No. & \multicolumn{1}{c}{ Property } & Whole turmeric rhizome & Cut turmeric rhizome pieces \\
\hline 1. & Length, $\mathrm{mm}$ & $54.46 \pm 8.45$ & $9.10 \pm 1.84$ \\
2. & Breadth, $\mathrm{mm}$ & $12.48 \pm 1.61$ & $6.37 \pm 1.06$ \\
3. & Thickness, $\mathrm{mm}$ & $11.32 \pm 1.41$ & $4.72 \pm 1.18$ \\
6. & Bulk density, $\mathrm{kg} / \mathrm{m}^{3}$ & $555.25 \pm 0.96$ & $725.1 \pm 1.02$ \\
\hline
\end{tabular}

\section{Cost economics}

Cost economics was done to find the cost of operation of pin mill. It was found that, the total hourly cost of pin mill ` $46.10 / \mathrm{hr}$ i.e. $1.70 / \mathrm{kg}$. This cost was very low as compared to cost of manual cutting.
Cutting of turmeric was pre-treatment given to the turmeric rhizome before grinding. Turmeric pieces were then fed into the pin mill for grinding.

The Developed pin mill was having a capacity of $25-27 \mathrm{~kg} / \mathrm{hr}$. 
Pin mill cut whole turmeric rhizome into small pieces which had the average length, width and thickness of $9.10 \pm 0.51,6.37 \pm 0.29$ and $4.72 \pm 0.32 \mathrm{~mm}$, respectively. It was also observed that bulk density of cut rhizome pieces was $725.1 \pm 0.00 \mathrm{~kg} / \mathrm{m}^{3}$.

This pin mill can also use other hard and long product to cut into small pieces.

\section{References}

Anonymous, 2015. Ministry of Agriculture. State Agri./Horticulture Departments, Directorate of Arecanut and Spices Development (DASD). Major Spice/state wise area and production of spices. Calicut, India.

Gopalkrishnan, M., Varma, R., Padmakumari,
K. P., Symon, B., Umma, H. and Narayan, C. S. 1991. Studies on cryogenic grinding of cardamom. Indian Perfumer. 35(1): 1-7.

Lal, J., 2012. Turmeric, curcumin and our life: A review. Bulletin of Environment, Pharmacology and Life Sciences. 1(7): 11-17.

Pruthi, J. S., 1998. Major spices of India crop management and post-harvest technology. $2^{\text {nd }}$ ed. Publications and Information Division, IARI, New Delhi, India.

Pruthi, J. S., and Mishra, B. D. 1963. Physical, chemical and microbial changes in curry powdes during drying, milling and mixing operations. Spice Bull. 3(8): 9-13.

\section{How to cite this article:}

Shelake, P.S., M.N. Dabhi, R.D. Nalawade and Jadhav, M.L. 2017. Design and Development of Pin Mill for Size Reduction of Turmeric (Curcuma longa) Rhizome. Int.J.Curr.Microbiol.App.Sci. 6(10): 2102-2107. doi: https://doi.org/10.20546/ijcmas.2017.610.250 